\title{
Kemampuan Menulis Aksara Sunda Siswa SMA/SMK se-Jawa Barat dalam Lomba Riksa Budaya Sunda 2018
}

\author{
Lita Utami \\ SMP Negeri 1 Depok \\ lita_utami@gmail.com
}

Sejarah Artikel: Diterima (05 Oktober 2018); Diperbaiki (15 November 2018); Disetujui (03 Januari 2019); Pusblished (30 April 2019).

Bagaimana mengutip artikel ini (dalam gaya APA): Utami, L. (2019). Kemampuan menulis Aksara Sunda siswa SMA/SMK se-Jawa Barat dalam lomba Riksa Budaya Sunda 2018. Lokabasa, 10(1), 111. doi: 10.17509/jlb.v10i1.16940

Abstrak: Tujuan penelitian ini yaitu untuk mendeskripsikan kemampuan menulis aksara Sunda siswa baik dalam huruf konsonan, 'rarangken', vokal, atau angka. Metode yang digunakan dalam penelitian ini yaitu metode deskriptif, dengan menggunakan tekhnik tes dan dokumentasi. Sumber data penelitian ini yaitu teks hasil lomba menulis aksara Sunda siswa SMA/SMK setara se-Jawa Barat, dengan jumlah 68 teks aksara Sunda. Hasil penelitian ini yaitu pertama, kemampuan siswa dalam menulis huruf konsonan dapat dikatakan mampu, dengan persentase $99.31 \%$. Terdapat 165 kesalahan yang dilakukan oleh siswa. Dengan kesalahan konsonan terdapat dalam huruf ja (a). Kedua, kemampuan siswa dalam menulis 'rarangken' dapat dikatakan mampu, dengan persentase $98.36 \%$. Terdapat 246 kesalahan yang dilakukan siswa. Dengan kesalahan terdapat dalam pamaéh (z). Ketiga, kemampuan siswa dalam menulis vokal dapat dikatakan mampu, dengan persentase $98.08 \%$, dengan jumlah kesalahan 39. Dengan kesalahan vokal terdapat dalam vokal "é" (3). Keempat, kemampuan siswa dalam menulis angka dapat dikatakan mampu, dengan persentase $91.1 \%$. Jumlah kesalahan 127. Dengan kesalahan angka dalam tanda mutlak ||. Berdasarkan hasil penelitian, disimpulkan bahwa kemampuan menulis aksara Sunda siswa dapat dikatakan mampu menulis aksara Sunda dengan benar, dengan persentase 63.22\%, atau 43 siswa dari 68 siswa yang mengikuti lomba.

Kata Kunci: Aksara Sunda; kemampuan menulis; lomba; RBS

\section{Sundanese Script Writing Ability of West Java Vocational and Senior High School Students in the 2018 Sundanese Culture Competition}

Abstract:This research was aimed at describing students' ability in writing Sundanese script i.e. consonant, conjunction, vocal, or numbers. This research employed a descriptive method, by using tests and documentation as its technique. The source of this research was 68 Sundanese script texts taken from the result of writing Sundanese script competition for vocational and senior high school students of west java. The result of this research revealed that: first, 99.31\%. of the students are able to write consonants. Though, there are 165 mistakes done by students in writing Ja (41) consonant letters. Second, 98.36\% of the students are able to write 'rarangken', but still, there are 246 mistakes done by students in writing pamaéh (z) 'rarangken' letters. Third, $98.08 \%$ of the students are able to write vocal. However, there are 39 mistakes done by students in writing "é” (ઉ) vocal letters. Fourth, 91.1\%. of the students are able to write numbers, while 127 mistakes of writing the absolute symbol (||) were still found. The research result revealed that the students of west java vocational and senior high school who are able in writing Sundanese script in Riksa Budaya Sunda 2018 were $63.22 \%$ or 43 students out of 68 contestant students.

Keywords: Sundanese script, writing ability, contest, RBS. 


\section{ENDAHULUAN}

Kegiatan menulis harus menjadi suatu kebiasaan bagi siswa. Karena menulis penting untuk kehidupan seharihari. Salah satu manfaatnya yaitu menuangkan ide dalam bentuk tulisan. Menurut Haerudin, dkk. (2013, hlm. 1), keterampilan bahasa dibagi menjadi empat aspek, yaitu memahami, bercerita, membaca, dan menulis, sedangkan menurut Mulyati (2015, hlm. 4), bahwa keterampilan bahasa dibagi menjadi dua bagian, yaitu aspek reseptif dan aspek produktif. Aspek reseptif bersifat menerima sedangkan aspek produktif bersifat menghasilkan.

Kemampuan siswa dalam menulis, khususnya menulis aksara Sunda, tentu setiap orang berbeda. Perbedaan itulah yang menjadi ciri khas atau kemampuan yang dimiliki siswa. Hasilnya bisa dikategorikan baik, cukup, kurang, dan lain sebagainya. Terutama dalam menulis huruf konsonan, vokal, 'rarangken' (tanda vokalisasi), dan angka. Dalam hal ketepatannya masih terdapat kesalahan. Kesimpulannya dalam menulis aksara Sunda harus memperhatikan kaidahkaidah aksara Sunda, sehingga hasil tulisannya baik dan benar.

Upaya untuk melestarikan aksara Sunda, diatur oleh pemerintah dengan adanya materi aksara Sunda dalam muatan lokal basa Sunda, yang terdapat dalam struktur kurikulum pendidikan dasar jenjang SD sampai jenjang SMA di Jawa Barat. Berdasarkan UUD 1945, BAB XV, pasal 36 bahwa "di daerah-daerah yang memiliki bahasa ibu, yang dipelihara oleh masyarakatnya sendiri, bahasa tersebut akan dipelihara oleh Negara." Aturan lainnya yaitu Perda No. 14 tahun 2014 yang membahas tentang upaya pelestarian bahasa, sastra, dan aksara daerah (Kemenhum, 2014, hlm.1). Tanggal 16 Juni 1999 ditetapkan dalam Surat Keputusan Gubernur Kepala Daerah Tingkat 1 Jawa Barat No.434/SK.614/dispk/1999 tentang pembakuan aksara Sunda (Baidillah dalam Apriani, 2016 hlm. 45).
Upaya pemerintah untuk melestarikan aksara Sunda, yaitu dengan diadakannya kegiatan-kegiatan, di antaranya lomba menulis dan membaca aksara Sunda, lomba lukisan aksara Sunda, dan lain-lain. Salah satu lomba yang diadakan oleh Himpunan Pendidikan Bahasa dan Sastra Sunda yaitu lomba menulis aksara Sunda Riksa Budaya Sunda 2018.

Banyaknya kesalahan yang dilakukan oleh siswa dalam menulis aksara Sunda, perlu diketahui kemampuannya. Oleh karena itu, penelitian ini membahas tentang kemampuan menulis aksara Sunda siswa SMA/SMK se-Jawa Barat dalam lomba Riksa Budaya Sunda 2018.

Kemampuan menurut Kamus Basa Sunda Danadibrata (2015, hlm. 424), berasal dari kata 'mampu' yang menggunakan kata depan ka-, mempunyai arti kuat, sanggup, bisa. Menurut Zain (dalam Sanjaya, 2014, hlm. 1), bahwa kemampuan merupakan suatu potensi yang terdapat dalam diri seseorang dengan usahanya sendiri. Sedangkan menurut Chomsky (dalam Haerudin, dkk. 2013, hlm. 2), yaitu kompetensi dan performansi. Kompetensi artinya kemampuan yang bersifat abstrak, terdapat dalam otak dan batin manusia yang merupakan pengetahuan dan sikap. Sedangkan performansi artinya kemampuan yang bersifat kongkrit. Yaitu terdapat dalam keterampilan bahasa, di antaranya mendengarkan, bercerita, membaca, dan menulis.

Menulis menurut Kamus Basa Sunda Satjadibrata (2005, hlm. 403) dan Danadibrata (2015, hlm. 713), berasal dari kata 'tulis' yang menggunakan kata depan $\mathrm{N}$-(nasal) yang mempunyai arti membuat aksara, angka, menulis menggunakan pensil di kertas. Sedangkan menurut Mc. Robert (dalam Kusmana, 2014, hlm. 16), bahwa menulis adalah berfikir dan menulis melibatkan aktivitas mengetahui apa pesan yang ingin disampaikan, siapa penerima pesan itu, dan bagaimana cara 
menyusun gagasan sehingga komunikasi yang dilakukan jelas. Menurut Tarigan (dalam Direktori, 2012, hlm.3), menulis merupakan kegiatan menurunkan lambang-lambang grafik yang menggambarkan suatu bahasa bisa dimengerti oleh seseorang, sehingga orang lain bisa membaca lambanglambang grafik, sehingga bisa memahami bahasa dan gambaran grafik tersebut.

Dalam proses menulis tidak langsung mahir menulis, perlunya langkah-langkah agar hasil tulisan baik. Terdapat beberapa proses kreatif dalam menulis menurut Akhadiah, dkk. (dalam Sardila, 2015, hlm. 114), di antaranya: 1) persiapan, pada tahap ini penulis menyadari apa yang akan ditulis; 2) inkubasi, pada tahap ini gagasan yang telah muncul tadi direnungkan kembali oleh penulis; 3) inspirasi, pada tahap ini penulis menyadari apa yang akan ditulis; 4) penulisan, pada tahap ini penulis mengungkapkan apa yang akan ditulis; 5) revisi.

Aksara Sunda berasal dari kata "Aksara" dan "Sunda". Aksara menurut Kamus Basa Sunda Danadibrata (2015, hlm.11), mempunyai arti 'gambar suara' yang disambungkan. Aksara merupakan salah satu ciri kemajuan bangsa serta sebagai alat untuk memajukan bangsa (Suryani, 2010 hlm. 1).

Dikatakan Suherman $(2017 ; 2019)$ bahwa aksara Sunda merupakan jenis aksara yang lahir dari periode klasik, untuk membedakannya dengan periode Islam yang ditandai dengan aksara Pegon dan periode kolonial yang ditandai dengan berkembangnya aksara Latin.

Menurut Baidillah, dkk (dalam Sudaryat, 2015, hlm. 162), bahwa aksara Sunda merupakan aksara tradisi yang menjadi ciri, jatidiri, dan kebanggaan suku bangsa Sunda sebagai pemilik tradisi. Aksara Sunda berkaitan dengan tiga hal, yakni (1) aksara Sunda langsung menunjuk pada suku bangsa Sunda yang menjadi pemilik aksara tersebut; (2) kenyataannya bahwa tidak semua bangsa memiliki sistem aksaranya sendiri; dan (3) aksara Sunda adalah sumber pembangunan jati diri bangsa yang keberadaannya akan menjadi kebanggaan suatu bangsa.

Rintisan dalam membuat font aksara Sunda mengalami perubahan setiap tahunnya. Bulan Juni tahun 2005 informasi mengenai aksara Sunda baku di mainglist, bulan Juli Font aksara Sunda dipresentasikan dalam Konferensi Bahasa Sunda VII tahun 2005 di Subang Jawa Barat oleh M. Sasmita. Tahun 2006 bulan Januari menghasilkan korespondensi mengenai rancangan font aksara Sunda oleh M. Everson. Kemudian mengajukan proposal font aksara Sunda kepada Unicode bulan Juni 2006. Bulan Agustus taun 2007 aksara Sunda lolos ke tahap VI standarisasi Unicode, kemudian menunggu dipublikasi. Taun 2008 bulan April aksara Sunda resmi menjadi standar Unicode. Tahun 2013 direvisi dari versi sebelumnya yaitu 1.0.5 menjadi versi 2 , perubahan terdapat dalam huruf ja yaitu layar yang sebelumnya menghadap ke kiri menjadi ke kanan (Aditiar, 2016 hlm. 14).

Dalam tata tulisnya, terdapat 7 macam aksara swara (vokal), dan 25 macam aksara silaba/konsonan, 13 'rarangken', yang dapat merubah, menambah, atau menghilangkan suara vokal dari aksara ngalagena. 13 'rarangken' tersebut dibagi menjadi tiga bagian. Masing-masing ditempatkan di bawah aksara ngalagena berjumlah 3, dan ditempatkan sejajar dengan aksara ngalagena berjumlah 5 .

Masing-masing dari bagian tersebut, 1 ditempatkan di sebelah kiri aksara ngalagena, 2 ditempatkan di sebelah kanan aksara ngalagena, dan 2 ditempatkan di sebelah kanan. Selain yang telah disebutkan di atas, terdapat lambang bilangan angka dasar yang mempunyai nilai hitungan dari nol sampai sembilan.

\section{METODE}

Penelitian ini merupakan penelitian kualitatif dengan menggunakan 
pendekatan deskriptif. Empat hal yang dilakukan dalam desain penelitian ini. Pertama, analisis huruf konsonan. Kedua, analisis tanda vokalisasi 'rarangkén'. Ketiga, analisis vokal, dan keempat analisis angka.

Sumber data penelitian ini yaitu teks hasil perlombaan menulis aksara Sunda siswa SMA/SMK setara se-Jawa Barat, dengan jumlah 68 peserta. Selain itu untuk membantu penelitian ini dengan menambahkan buku-buku sumber yang berkaitan dengan materi yang diteliti.

Instrumen yang digunakan dalam penelitian ini menggunakan lembaran tes, kartu data, dan rubrik penilaian. Jumlah soal tes yang diberikan pada peserta adalah 10 soal, dengan transliterasi dari huruf Latin ke aksara Sunda. Menurut Arikunto (2010, hlm. 203), instrumen penelitian merupakan alat atau fasilitas yang digunakan oleh peneliti dalam mengumpulkan data sehingga pekerjaannya menjadi ringan dan lebih baik, dalam arti lebih teliti, lengkap, dan sistematis yang menjadikan data lebih mudah diolah.

Teknik mengumpulkan data dalam penelitian ini adalah teknik tes dan dokumentasi. Sedangkan teknik yang digunakan dalam mengolah data adalah analisis pada kemampuan menulis aksara Sunda huruf konsonan, tanda vokalisasi, 'rarangken' dan angka.

\section{HASIL DAN PEMBAHASAN}

Berdasarkan pada hasil penelitian mengenai kemampuan menulis aksara Sunda, ditemukan hasil kemampuan menulis huruf konsonan, 'rarangken', vokal, dan angka.

\section{Kemampuan Siswa SMA/SMK Se- Jawa Barat dalam Menulis Huruf Konsonan (Silaba) Aksara Sunda}

Aksara Sunda silaba/konsonan merupakan lambang suara yang biasa disebut fonem konsonan dan secara silabis mengandung vokal/a/ (Faturohman, 2017, hlm. 106).
Berdasarkan hasil data yang dianalisis, kemampuan menulis aksara Sunda siswa SMA dengan persentase 99.31\%. Dengan jumlah data kesalahan siswa menulis huruf konsonan terdapat 165 kesalahan. Diantaranya 73 kesalahan menulis konsonan ja, 38 konsona pa, 8 kesalahan dalam konsonan sa, 12 konsonan na, 8 konsonan da, 6 konsonan ha, 4 konsonan ba, 7 konsonan ka, 1 konsonan ya, 3 konsonan nya, 2 konsonan ta, 2 konsonan ca, 3 konsonan ra, 4 konsonan ga, 2 konsonan wa, dan 1 konsonan la.

Kesalahan terbanyak huruf konsonan yaitu konsonan Ja (a). Siswa masih tertukar antara ja versi 1.0 .5 dan ja versi 2. Berdasarkan hasil data, siswa masih banyak yang menggunakan ja versi 1.0.5. Contoh kesalahan peserta seperti gambar di bawah ini.

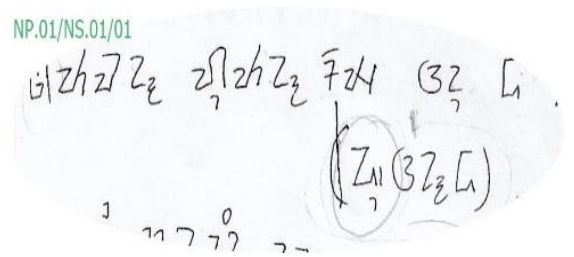

Gambar 4.1 Kesalahan Menulis Aksara ja Versi 2 ditulis Vérsi 1.0.5

Berdasarkan gambar di atas, kesalahan yang dilakukan oleh siswa dengan nomor peserta 1 yaitu menulis huruf ja menggunakan versi 1.0.5. Sedangkan versi yang dijadikan aturan dalam lomba yaitu menggunakan versi 2 . Kata "Juanda" yang seharusnya ditulis $\underline{A}_{7}\left(3 Z_{2} \Omega\right.$, tapi yang ditulis oleh peserta juAn;d. Ja yang digunakan yaitu ja versi 2. Artinya kemampuan siswa dengan nomor peserta 1 dapat dikategorikan baik.

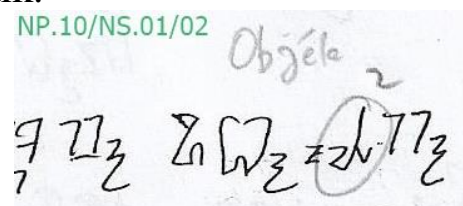

Gambar 4.3 Kesalahan Menulis Aksara ja ditulis ya 
Berdasarkan gambar di atas, kesalahan yang dilakukan oleh siswa nomor peserta 10, terdapat dalam konsonan ya. Kata "objék" seharusnya ditulis $\ln \left[\nabla_{\xi} Z L_{1} 77_{\xi}\right.$, tapi yang dilakukan oleh peserta nomor 10 menggunakan konsonan ya $\operatorname{Zn}_{n} \mathcal{D}_{\xi z} Z N 77_{\xi}$. Seharusnya ditulis konsonan ja tapi ditulis ya. Hal ini dikarenakan peserta masih tertukar ketika menulis kata "objék", tapi berdasarkan Kamus Basa Sunda Danadibrata, ditulis menggunakan konsonan ja. Kemampuan siswa dengan nomor peserta 10 bisa dikategorikan cukup.

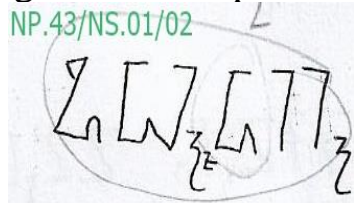

Gambar 4.4 Kesalahan Menulis Aksara ja ditulis da

Gambar di atas kesalahan yang dilakukan oleh siswa nomor peserta 43, yaitu konsonan da. Seharusnya kata "objék" ditulis $\operatorname{Zn}_{n}\left[\nabla_{z} L_{\mathbf{A}} 77_{z}\right.$, sedangkan siswa menulis $\operatorname{Zn}_{n} \mathrm{~N}_{\xi z}\left[\mathbf{A} 77_{z}\right.$. Seharusnya konsonan ja tapi yang ditulis oleh siswa konsonan da. Hal ini dikarenakan konsonan ja dan konsonan da hampir sama, perbedaannya konsonan ja terdapat garis sejajar di sebelah kanan. Kemampuan siswa dengan nomor peserta 43 dapat dikategorikan cukup.

$$
\begin{aligned}
& \text { NP.02/NS.06/12 }
\end{aligned}
$$

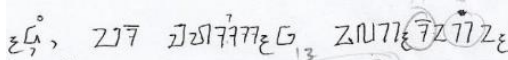

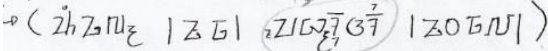

Gambar 4.5 Kesalahan Nulis Aksara Pa yang ditulis Aksara Fa

Kesalahan yang dilakukan oleh siswa nomor peserta 2 yaitu konsonan Pa yang ditulis konsonan Fa. Contohnya kata "Pébruari", seharusnya menggunakan konsonan Pa bukan Fa, karena dalam bahasa Sunda tidak ada huruf F. Sehingga

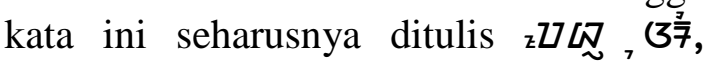

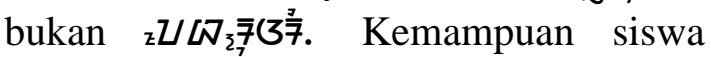

dengan nomor peserta 2 dapat dikategorikan masih kurang.

NP.21/NS.06/8 l 'Ld) LU //

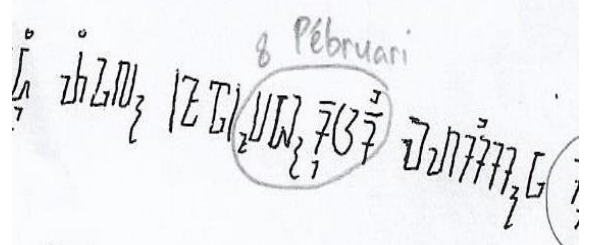

Gambar 4.6 Kasalahan Menulis Aksara Pa yang ditulis Aksara Va

Gambar di atas menjelaskan bahwa siswa nomor peserta 21 terdapat kesalahan dalam menulis kata "Pébruari". Seharusnya menggunakan konsonan Pa, tapi yang ditulis siswa konsonan Va. Seharusnya ditulis $z \longrightarrow\left[\mathbb{N}_{7}\right.$ (37),

bukan $z U\left[\boldsymbol{V}_{2,7} \overline{7} \mathbf{3}^{\frac{3}{7}}\right.$. Masih tertukar antara konsonan $\mathrm{P}$ dan $\mathrm{F}$. Kemampuan siswa nomor peserta 21 dapat dikategorikan baik.

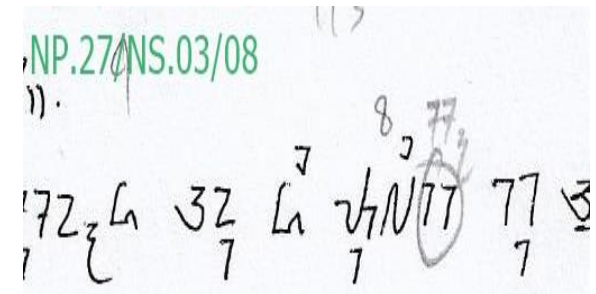

Gambar 4.12 Kesalahan Menulis Aksara Sa yang ditulis Aksara Ka

Gambar di atas merupakan kesalahan siswa dengan nomor peserta 27. Seharusnya ditulis konsonan sa tapi yang ditulis siswa konsonan ka. Kata "ditulis"

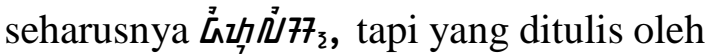

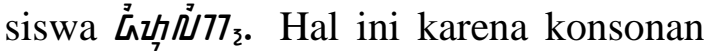
ka dan sa hampir sama, akan tetapi bedanya konsonan sa terdapat garis di tengah. Sedangkan konsonan ka tidak terdapat garis. Kemampuan siswa dengan nomor peserta 27 dapat dikategorikan masih kurang.

Kemampuan Siswa SMA/SMK SeJawa Barat dalam Menulis Huruf 'rarangken' Aksara Sunda

'rarangken' merupakan suatu lambang untuk merubah suara (vokal). (Faturohman, 2017, hlm. 106).

Berdasarkan data hasil analisis, kemampuan siswa menulis 'rarangken' 
sudah dapat dikatakan mampu, dengan persentase $98.36 \%$. Terdapat 246 kesalahan yang dilakukan oleh siswa menulis 'rarangken'. Yaitu 39 pamepet, 6 paneuleung, 8 pangwisad, 31 panéléng, 42 pamaéh, 38 panglayar, 18 panghulu, 31 pamingkal, 3 panyakra, 14 panyuku, 13 panyecek, dan 3 panolong.

Dapat disimpulkan banyaknya kesalahan 'rarangken' terdapat dalam pamaéh (z) dengan jumlah kesalahan 42 . Kesalahan yang dilakukan oleh peserta yaitu huruf konsonan yang tidak memakai pamaéh. Contohnya kata "lembaga",

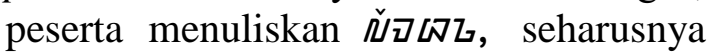
setelah konsonan ma menggunakan pamaéh, yang menjadi $\check{\nu}_{\Sigma} \measuredangle \mathbf{Z} Z$. Selain itu kata "Juanda", yang ditulis oleh peserta 4̇3Za. Setelah konsonan na tidak menggunakan pamaéh, penulisan yang benar $\bar{L}_{7}\left(3 Z_{3} \bar{A}\right.$. Contoh gambar terdapat di bawah ini.

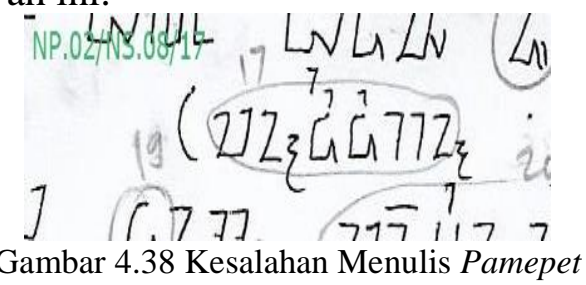

Kesalahan yang dilakukan oleh siswa dengan nomor peserta 2 yaitu dalam menulis pamepet. Kata "pendidikan",

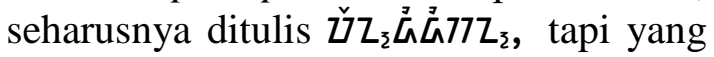
ditulis oleh siswa tidak menggunakan pamepet. Sedangkan yang ditulis oleh

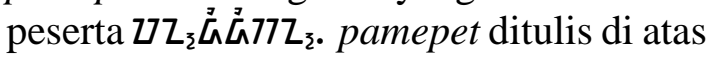
huruf konsonan. Kemampuan siswa dengan nomor peserta 2 dapat dikategorikan masih kurang.

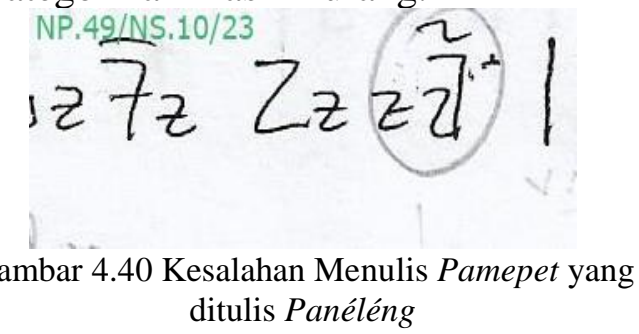

Kesalahan siswa dengan nomor peserta 49 yaitu menulis pamepet yang ditulis panéléng. Kata "nomer" seharusnya ditulis $Z_{z} \check{z}^{\sim}$, tapi yang ditulis oleh siswa menggunakan panéléng, jadi $Z_{z z z}$. Hal ini dikarenakan siswa masih tertukar dalam menulis kata "nomer", tapi berdasarkan Kamus Basa Sunda Danadibrata ditulis "nomer", tidak menggunakan vokal é. Kemampuan siswa dengan nomor peserta 49 dapat dikategorikan masih kurang.

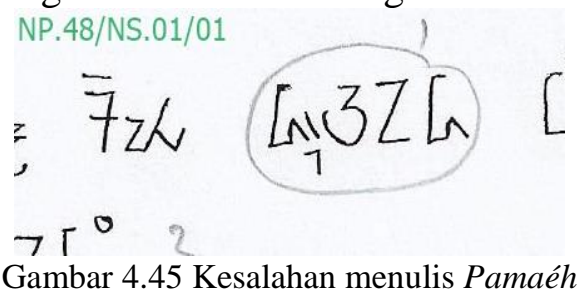

Gambar di atas adalah kesalahan peserta nomor 48 yaitu dalam penulisan pamaéh. Kata "Juanda" yang seharusnya ditulis $L_{1}\left(3 Z_{3} \Omega\right.$, tapi yang ditulis oleh peserta A BZI, tidak menggunakan pamaéh. Seharusnya setelah vokal a menggunakan pamaéh. Kemampuan siswa dengan nomor peserta 48 dapat dikategorikan cukup.

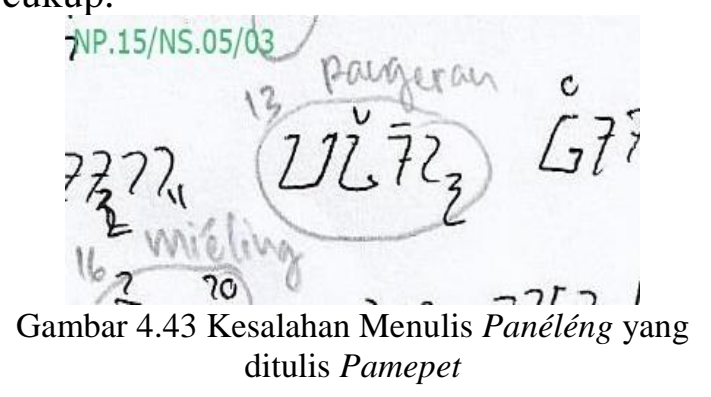

Kesalahan siswa dengan nomor peserta 15 yaitu menulis panéléng ditulis pamepet. Kata "pangéran" seharusnya

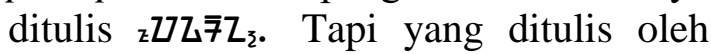
siswa menggunakan pamepet, jadi ditulis 乙乙̌ $\overline{\mathbf{z}} \mathrm{Z}_{3}$. Hal ini sering terjadi dikarenakan masih tertukar antara vokal e dengan é. Kemampuan siswa dengan nomor peserta 15 dikategorikan kurang.

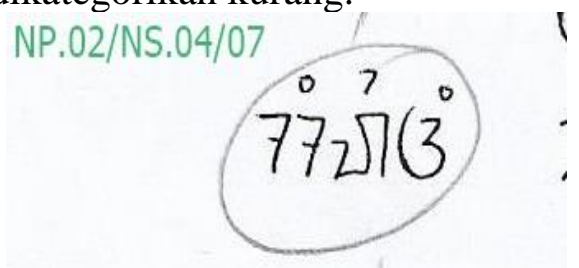

Gambar 4.49 Kesalahan Menulis Pamingkal 
Kesalahan siswa nomor peserta 11 yaitu tidak menuliskan pamingkal. Seharusnya kata "sanghyang" ditulis $77_{2}^{\circ}$, tapi yang ditulis oleh siswa tidak menggunakan pamingkal setelah

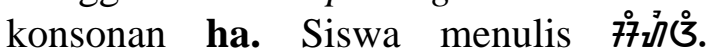
Kemampuan siswa dengan nomor peserta 2 dikategorikan masih kurang.

\section{Kemampuan Siswa SMA/SMK Se- Jawa Barat dalam Menulis Aksara Swara/Vokal}

Aksara swara/vokal merupakan aksara yang memiliki suara vokal. Kemampuan siswa menulis vokal dikategorikan baik dengan persentase 98.08\%. Kesalahan penulisan aksara vokal berjumlah 39, meliputi kesalahan vokal "ée" berjumlah 16, kesalahan vokal "i" ada 13 kesalahan, vokal "a" sebanyak tiga, dan vokal "u" sebanyak tujuh.

Kesalahan terbanyak dalam aksara vokal adalah vokal "é". Diantaranya kesalahan penulisan vokal "é" ditulis menggunakan vokal "a", vokal "e" ditulis vokal "a", vokal "i" ditulis dengan konsonan "ya", vokal "a" ditulis dengan konsonan ha. Dalam kata "nya éta", peserta menggunakan vokal "e" yang seharusnya menggunakan vokal "é". Siswa menulis $Z \nabla \circlearrowleft \downarrow h$ yang seharusnya ZNઉュh. Kata "daérah", siswa menulis $\mathbf{G} \mathbf{3} \overline{\bar{z}}$, seharunya ditulis $\mathbf{G} \mathbf{3} \overline{\bar{z}}$.

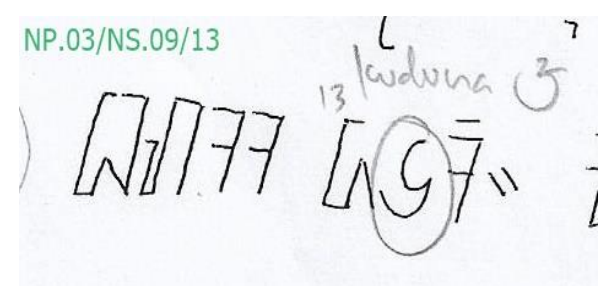

Gambar 4.53 Kesalahan Penulisan Vokal "é" ditulis Vokal "e"

Kesalahan yang dilakukan oleh siswa dengan nomor peserta 3 menulis vokal "e". Kata "daérah" seharusnya

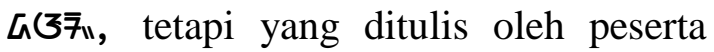

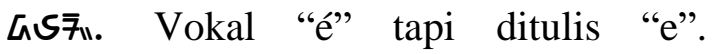
Kemampuan siswa dengan nomor peserta 3 dikategorikan masih kurang.

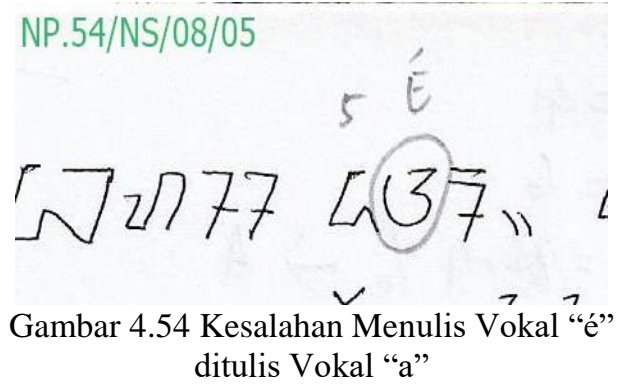

Kesalahan yang dilakukan siswa dengan nomor peserta 54 yaitu vokal "é" ditulis vokal "e". Kata "daérah" seharusnya ditulis $\mathbf{C} \mathbf{G} \overline{\mathbf{7}} \|$, tapi yang ditulis oleh siswa menggunakan vokal "a", jadi [137... Bentuk vokal é dan a hampir sama, bedanya vokal "é" terdapat garis melengkung di tengah. Kemampuan siswa dengan nomor 54 dikategorikan baik.

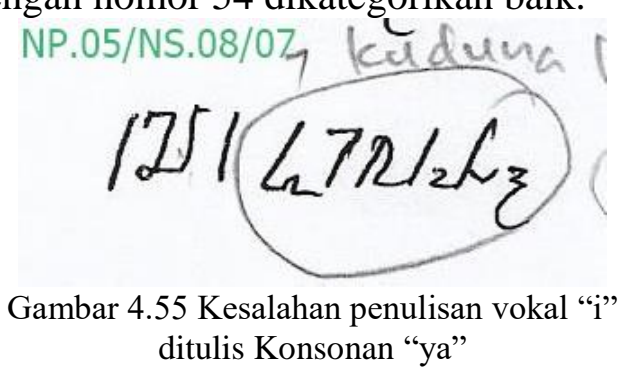

Kesalahan yang dilakukan siswa nomor peserta 5 yaitu menulis kata

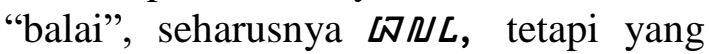
ditulis oleh siswa $\mathbb{L} \Omega \mathcal{L}$, yang seharusnya vokal "i" ditulis dengan konsonan ya. Berdasarkan Kamus Basa Sunda Danadibrata, kata "balai" ditulis i. Kemampuan siswa dengan nomor peserta 5 dapat dikategorikan baik.

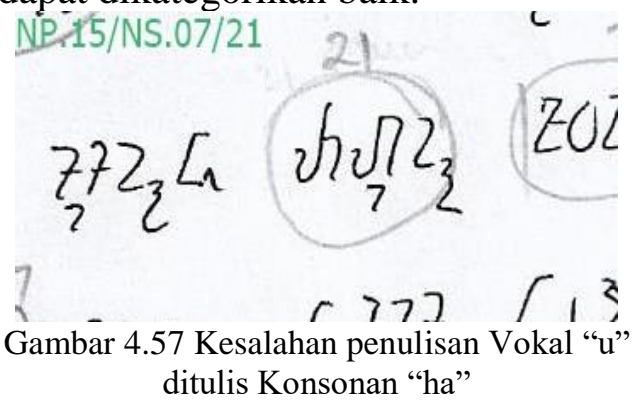

Kesalahan yang dilakukan oleh siswa nomor peserta 15 ditemukan dalam penulisan vokal. Menulis kata "taun" seharusnya ditulis $z h z_{s} z_{z}$, tetapi yang ditulis oleh siswa $\mathrm{Zh}_{7} \mathrm{Z}_{\check{\Sigma}}$. Vokal " $\mathrm{u}$ " dengan konsonan ha. Dalam bahasa 
Sunda, menulis kata "taun" tidak menggunakan konsonan ha. Tetapi menggunakan vokal "u". Kemampuan siswa dengan nomor peserta 15 dikategorikan masih kurang.

\section{Kemampuan Siswa SMA/SMK Se- Jawa Barat dalam Menulis Angka Aksara Sunda}

Angka merupakan lambang bilangan. Menulis lambang angka puluhan, ratusan, dan seterusnya ditulis dari sebelah kiri ke sebelah kanan. Angka ditulis di antara dua garis yang disebut tanda mutlak $|\tau|$.

Berdasarkan hasil penelitian, kemampuan siswa menulis angka dapat dikatakan mampu, dengan persentase 91.1\%. Kesalahan angka berjumlah 127. Hal ini disebabkan menulis angka tidak menggunakan tanda mutlak. Kesalahan terdiri dari menulis angka ditulis konsonan berjumlah 21, kesalahan tanda mutlak sebanyak 72, 10 kesalahan menggunakan tanda kurung, dan 24 kesalahan tertukarnya angka. Banyaknya kesalahan yang dilakukan oleh peserta dalam menulis angka yaitu dalam tanda mutlak, yang berjumlah 72. Siswa menuliskan angka dengan menggunakan tanda mutlak satu, tidak menggunakan tanda mutlak dua, dan menggunakan tanda kurung. Contoh kesalahan peserta seperti gambar di bawah ini.

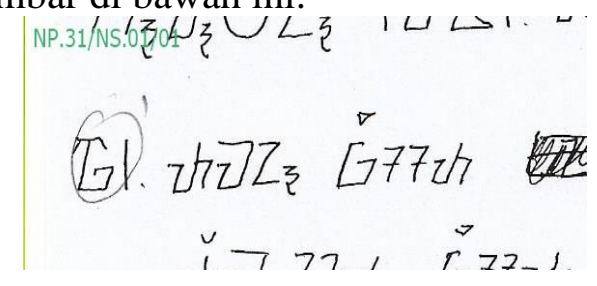

Gambar 4.58 Kesalahan Menulis Angka Tanda Mutlak Satu

Berdasarkan gambar di atas, kesalahan yang dilakukan oleh siswa dengan nomor 31 yaitu menulis angka tidak menggunakan tanda mutlak dua. Tetapi siswa menulis dengan tanda mutlak satu. Angka di atas merupakan angka 1, siswa menulis $\tau \mid$, penulisan yang benar yaitu ditulis $|\boldsymbol{G}|$. Kemampuan siswa dengan nomor peserta 31 dikategorikan masih kurang.

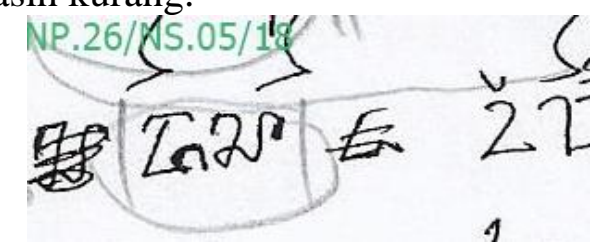

Gambar 4.59 Kesalahan Menulis Angka Tidak Menggunakan Tanda Mutlak

Kesalahan yang dilakukan oleh peserta nomor 26 yaitu menulis angka tidak menggunakan tanda mutlak. Angka 98 seharusnya ditulis $\left|\tau_{\delta} \mathbb{J}\right|$, tetapi yang ditulis oleh siswa tidak menggunakan tanda mutlak, jadi $\mathbb{E} \mathbb{J}$. Kemampuan siswa dengan nomor peserta 26 dikategorikan kurang.

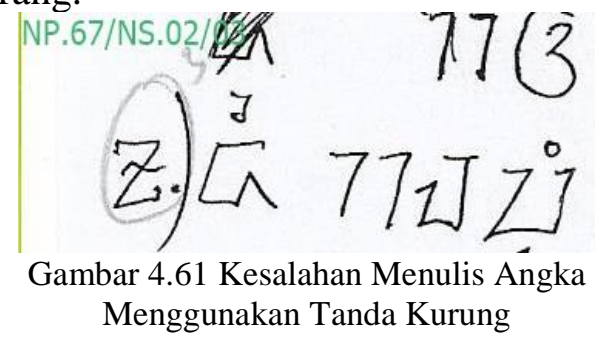

Kesalahan siswa dengan nomor peserta 67 yaitu tanda kurung. Seharusnya menulis angka ditulis tanda mutlak dua, bukan memakai tanda kurung. Angka 2 seharusnya ditulis $|z|$, tetapi yang ditulis oleh siswa Z ). Kemampuan siswa dengan nomor peserta 67 dikategorikan masih kurang.

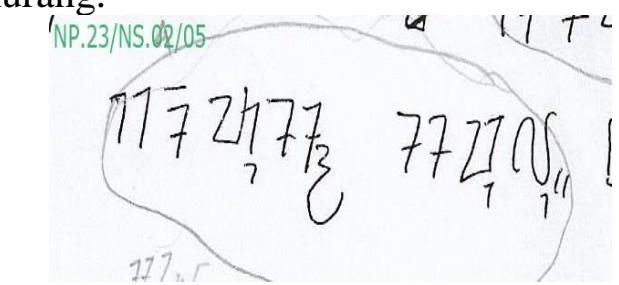

Gambar 4.60 Kesalahan Menulis Angka ditulis Konsonan

Kesalahan siswa dengan nomor peserta 23 yaitu menulis angka dengan huruf konsonan. Angka 110 seharusnya ditulis $\mid$ GLO|, tetapi yang digunakan oleh siswa menulis dengan huruf konsonan. Hal ini dikarenakan siswa belum mengetahui cara penulisan angka dengan 
benar. Kemampuan siswa dengan nomor peserta 23 masih kurang.

\section{SIMPULAN}

Aksara menjadi satu hal yang harus diketahui oleh masyarakat. Khususnya masyarakat Sunda. Baik di dunia pendidikan, atau di luar pendidikan, mempelajari aksara asli Sunda penting dalam kehidupan. Di dunia pendidikan bisa dijadikan bahan ajar materi aksara Sunda. Sedangkan di luar pendidikan untuk menambah keterampilan menulis aksara Sunda, sehingga tidak terjadi kesalahan dalam menulis aksara Sunda.

Berdasarkan hasil penelitian, kemampuan siswa menulis huruf konsonan dikategorikan baik sekali dengan persentase $99.31 \%$. Dilihat dari jumlah kesalahan terdapat 165 kesalahan. Dengan kesalahan terbanyak yaitu konsonan ja. Hal ini karena siswa menulis konsonan ja versi 1.0.5, sedangkan versi yang menjadi aturan dalam lomba menggunakan versi 2, sehingga siswa keliru dalam menggunakan konsonan ja.

Kemampuan siswa dalam menulis 'rarangkén' dikategorikan baik sekali, dengan persentase $98.36 \%$. Terdapat 246 kesalahan, dengan kesalahan terbanyak yaitu dalam pamaéh (z). Hal ini dikarenakan kurangnya pengetahuan siswa untuk menempatkan 'rarangkén'.

Kemampuan siswa menulis vokal dikategorikan baik sekali, dengan persentase $98.08 \%$. Dilihat dari jumlah kesalahan terdapat 39 kesalahan. Dengan banyaknya kesalahan terdapat dalam vokal "é". Hal ini siswa masih tertukar dengan vokal "e". Dan tertukar dengan vokal "a", karena vokal "é" dan "a" hampir sama bentuknya. Akan tetapi bedanya vokal é terdapat garis di tengah.

Kemampuan siswa menulis angka dikategorikan baik sekali, dengan persentase $91.1 \%$. Dilihat dari jumlahnya terdapat 127 kesalahan. Terdiri darikesalahan menulis angka 21, kesalahan tanda mutlak 72, kesalahan menggunakan tanda kurung 10, dan kesalahan tertukarnya angka 24. Kesalahan terbanyak di angka yaitu menuliskan tanda mutlak.

Berdasarkan beberapa penjelasan di atas, dapat disimpulkan bahwa kemampuan menulis aksara Sunda siswa dalam lomba Riksa Budaya Sunda 2018 dikategorikan sudah mampu. Karena siswa yang dianggap mampu yaitu siswa yang mendapatkan nilai $\mathrm{C}$ ke atas. Berdasarkan data yang diteliti, hasil kemampuan siswa dalam ketepatannya $63.22 \%$, dengan jumlah 43 dari 68 siswa yang mengikuti lomba.

Faktor yang menyebabkan banyaknya kesalahan dalam menulis aksara Sunda menurut Husen, dkk (2015, hlm. 885), diantaranya proses mengajarkan aksara Sunda yang kurang efektif. Sedangkan menurut Apriani (2016, hlm. 45), faktornya karena aksara Sunda kurang dikenalkan, terutama dalam memperkenalkan bentuk-bentuk aksara Sunda berdasarkan kaidah-kaidahnya.

\section{UCAPAN TERIMA KASIH}

Penulis mengucapkan terima kasih kepada tim penyunting jurnal Lokabasa atas dipublikasikannya penelitian ini.

\section{CATATAN PENULIS}

Penulis menyatakan bahwa tidak ada konflik kepentingan terkait publikasi artikel ini. Penulis mengkonfirmasi bahwa data dan artikel ini bebas plagiarisme.

\section{PUSTAKA RUJUKAN}

Aditiar, E. (2016). Média Game Flash dina Pangajaran Maca Aksara Sunda (Studi Kuasi Ékspérimén ka Kelas V-A SD Laboratorium Percontohan UPI Taun Ajaran 2015/2016). Skripsi DPBD FPBS UPI Bandung: tidak diterbitkan.

Arikunto, S. (2010). Prosedur Penelitian Suatu Pendekatan Praktik. Jakarta: Rineka Cipta.

Apriani, H. (2016). "Pangaruh Métode Iqra dina Pangajaran Maca Aksara 
Sunda Kana Kamampuh Nulis Aksara Sunda." Jurnal Lokabasa, vol.7, No.1 diaksés di ejournal.upi.edu.

Baidillah, I, dkk. (2008). Direktori Aksara Sunda untuk Unicode. Bandung: Dinas Pendidikan Provinsi Jawa Barat.

Danadibrata, R.A. (2015). Kamus Basa Sunda. Bandung: Kiblat Buku Utama

Direktori File UPI. (2012). Menulis dan Pembelajarannya. [online] tiasa diaksés di File.upi.edu Diakses pada tanggal 5 Oktober 2017.

Faturohman, T. (2017). Cahara Basa Pangajaran Basa Sunda Pikeun Murid SMA/SMK/MA Kelas X. Bandung: Geger Sunten.

Haerudin, D. dkk. (2013). Panganteur Kaparigelan Ngaregepkeun. Bandung: DPBD FPBS UPI.

Husen, dkk. (2015). "Perancangan dan Implementasi Aplikasi "Belajar Aksara Sunda" Berbasis Android di Sekolah Mengah Atas Negeri 1 Tasikmalaya." Jurnal e-Proceeding of Applied Science, vol.1, No.1.

Kemenhum RI. (2014). Peraturan Daerah Provinsi Jawa Barat Nomor 14 Tahun 2014. [Online] dapat diunduh di peraturan.go.id/perda/provinsijawa-barat-nomor-14-tahun2014.html.

Kusmana, S. (2014). Kreativitas Menulis. Yogyakarta: Penerbit Ombak
Mulyati, Y. (2015). Modul Hakikat Keterampilan Berbahasa. [Online]. dapat diaksés di repository.utac.id diaksés tanggal 29 Séptémber 2017.

Sanjaya, A. (2014). Pengertian Kemampuan Menurut para Ahli. [Online] dapat diaksés di http://www.landasanteori.com/2015 /10/pengertian-kemampuanmenurut-definisi.html diaksés tanggal 5 Pébruari 2018.

Sardila, V. (2015). "Strategi Pengembangan Linguistik Terapan Melalui Kemampuan Menulis Biografi dan Autobiografi: Sebuah Upaya Membangun Keterampilan Menulis Kreatif Mahasiswa." Jurnal: Pemikiran Islam, 40 ( 2).

Satjadibrata, R. (2005). Kamus Basa Sunda. Bandung: PT Kiblat Buku Utama.

Sudaryat, Y. (2015). Wawasan Kesundaan. Bandung: UPI Press.

Suherman, A. (2017). "Wawacan Pandita Sawang sebagai Naskah Keagamaan: Tinjauan Kedudukan dan Fungsi”. Manuskripta, 7 (2), hlm. 34-48.

Suherman, A. (2019). "Literacy Tradition of Sundanese Society - Indonesia: An annotation of the 16th Century Ancient Manuscript". IJIER International Journal for Innovation and Research, 7 (3).

Suryani, E. (2010). Calakan, Aksara, Basa, Sastra, Katut Budaya Sunda. Bogor: Ghalia Indonesia 